\title{
Payments for environmental services, gendered livelihoods and forest management in Vietnam: a feminist political ecology perspective
}

\author{
Wouter Tuijnman ${ }^{1}$ a \\ Mucahid Mustafa Bayrak b \\ Pham Xuan Hung ${ }^{c}$ \\ Bui Duc Tinh ${ }^{\mathrm{c}}$ \\ ${ }^{a}$ Vrije Universiteit Amsterdam, the Netherlands \\ b National Taiwan Normal University, Taiwan \\ c Hue College of Economics, Hue University, Vietnam
}

\begin{abstract}
Economic approaches to combat environmental degradation and deforestation have resulted in development initiatives such as the Payment for Environmental Services program (PES). This study deals with the effects of PES on women's livelihoods in Thuong Lo commune, Central Vietnam. Employing a feminist political ecology perspective and adopting a qualitative approach, we analyze the gendered roles, responsibilities and effects of PES on local livelihoods. We found that the women in our study portrayed different preferences and knowledge in relation to PES, forest management and livelihoods. Women are often excluded in PES projects due to a range of various socio-cultural factors.
\end{abstract}

Keywords: Payments for Environmental Services; forest management; gender; women's empowerment; livelihoods; Central Vietnam; Co Tu people

\section{Résumé}

Les approches économiques pour lutter contre la dégradation de l'environnement ont donné lieu à des initiatives de développement comme le programme de Paiement des Services Environnementaux (PSE). Cette étude-ci s'agit des effets de PSE sur les moyens de subsistance de femmes dans la communauté Thuong Lo, au Vietnam central. Utilisant une perspective fondée sur l'écologie politique féministe et une méthode de recherche qualitative, on analyse les rôles sexués, les responsabilités et les effets de PSE sur les moyens locaux de

\footnotetext{
1 Wouter Tuijnman, International Office, Vrije Universiteit Amsterdam, Amsterdam, the Netherlands. Email: woutertuijnman "at" hotmail.com. Dr. Mucahid Mustafa Bayrak (Corresponding Author), Assistant Professor, Department of Geography, National Taiwan Normal University, Taipei City, Taiwan. Email: mmbayrak "at" ntnu.edu.tw or mmbayrak "at" link.cuhk.edu.hk. Dr. Pham Xuan Hung, Head of International Cooperation Department, Hue College of Economics, Hue University, Hue City, Vietnam. Email: pxhung "at" hce.edu.vn. Dr. Bui Duc Tinh, Dean of Faculty of Economics and Development Studies, Hue College of Economics, Hue University, Hue City, Vietnam. Email: bdtinh "at" yahoo.com.sg. Acknowledgements: This study was conducted at the Faculty of Geosciences, Utrecht University as part of the International Development Studies MSc program. We would like to thank Hue College of Economics, Hue University for hosting the study as well as Tropenbos International Vietnam (TBI). Special thanks to Mr. Quong Quoc, Ms. Nguyen Thanh Minh and Ms. Truong Ngoc Minh Chau for their assistance in the field. Thank you also to Mr. Man Ngo, Mr. Ngoc Liem Le and Mr. Tran Huu Nghi (TBI). Dr. Jeroen van Bekhoven and Ms. Janin Mendoza helped us with the French and Spanish abstracts (merci and gracias!), and our sincere gratitude also extends to the JPE editor and reviewer. Last but not least, we would like to thank the households of Thuong Lo commune as well as the local officials and other people who participated in this research.
} 
subsistance. Les femmes dans cette étude ont exprimé des préférences et des connaissances différentes par rapport au PSE, l'aménagement forestier et les moyens de subsistance. Les femmes souvent sont exclues du PSE à cause d'une variété de facteurs socio-culturels.

Mots-clés: Paiement des Services Environnementaux; l'aménagement forestier; sexe; émancipation des femmes; moyens de subsistance; Vietnam central; peuple Co Tu

\section{Resumen}

Las diferentes estrategias económicas para luchar contra el deterioro ambiental y la deforestación han resultado en iniciativas de desarrollo como el programa de Pago por Servicios Ambientales (PSA). Este estudio trata acerca de los efectos de PSA sobre los medios de subsistencia locales de las mujeres en la comunidad Thuong Lo, en Vietnam Central. Utilizando una perspectiva ecología política feminista y un método cualitativo, analizamos las funciones de los géneros, responsabilidades y los efectos de PSA en los medios de subsistencia locales. En este estudio, alegamos que las mujeres en este estudio reflejaron preferencias y conocimientos diferentes respecto al PSA, la gestión forestal y los medios de subsistencia. Generalmente las mujeres están excluidas de PSA debido a una variedad de factores socio-culturales.

Palabras clave: Pagos por Servicios Ambientales; gestión forestal; género; empoderamiento femenino; medios de subsistencia; Vietnam Central; Pueblo Co Tu

\section{Introduction}

Economic approaches to combat environmental degradation and deforestation have resulted in development initiatives such as the Payment for Ecosystem or Environmental Services program (PES). PES refers to a suite of market driven and neoliberal mechanisms where certain stimuli, usually monetary, are given to local landholders, farmers, or communities as a whole. In return for these stimuli, these individuals or groups provide a certain environmental service (ES) by managing the land (or other natural resource) as requested by the party demanding these environmental services (Pham et al. 2013). Wunder (2005) describes PES as a voluntary transaction, where (a well-defined) environmental service (ES) is being bought by a minimum of one ES buyer, from a minimum of one ES provider and only if the ES provider secures ES provision. Since its early conception, monetization of environmental services has grown rapidly and has been incorporated, albeit to a lesser extent, into markets and payment mechanisms (Gómez-Baggethun et al. 2010). As such, these schemes have transcended the academic field to obtain a purpose in private, public, non-profit, and governmental fields as well as being used as a means to combat environmental degradation (Bayon 2004; Kumar 2010). Yet, PES can have a range of unforeseen consequences on communities (Wunder 2005, 2007). Depending on how payments interact with national, regional and local conditions, the commodification of environmental/ecosystem services and neoliberalization of forest protection, for example, could negatively affect the property rights of the targeted resources, local socio-political relations, livelihood transitions, cultural dynamics, landscape changes and gender roles (Escobar 1996, 1998; Haas et al. 2019; Phuc et al. 2012).

PES programs in Vietnam tend to be quite different from general PES structures (as described above) as they are only seen as a part of the government's policies in natural resource management. Moreover, the government defines the payment framework, regulates payments, decides on the types of services, identifies the buyers and sellers of environmental services, and ensures that the 'transaction' or the payments actually occur. The type of environmental service is not well defined, and the provision of the services is not secured (Suhardiman et al. 2013). In short, Vietnam largely adopts a 'command and control' or top-down approach, which is based on government policy rather than the market. This leads to an apparent path dependency of policies on forest management in Vietnam (Traedal et al. 2016). PES in Vietnam has, so far, seemed to ignore issues surrounding tensions between ethnic groups, pre-existing inequalities and land rights (Traedal et al. 2016). This aptly illustrates the importance of involving different institutions, organizations and other stakeholders in PES (Pham et al. 2010). Even though the true extent of the 'command and control' structure is unclear, it is apparent that it is an issue in policy making in Vietnam. Policymakers must counteract the pathdependent institutional reproduction of older structural inequalities and its conceptions of 'good' forest management to allow PES to become more socially inclusive (Suhardiman et al. 2013; Traedal et al. 2016). 
Women are often excluded from conservation projects, such as PES, due to a range of different factors, such as gender discrimination, social norms that dictate work distribution by gender, and social perceptions of the abilities of each gender (Agarwal 2001; Schwartz 2017). The impact of gender in a range of conservation activities, such as community forestry, has been researched extensively (Agarwal 2000, 2009; Nightingale 2002). Women's groups are often involved in forest activities. They collect Non-Timber Forest Products (NTFPs), such as firewood and fodder, and often have different views and knowledge on forest management and ecosystems (Agarwal 2000, 2009). Thus, there are gendered forest-based livelihoods that need to be acknowledged by conservation projects on forestry to ensure equity, as it is increasingly accepted that integrating social equity into environmental management planning is essential to achieve more robust socioecological outcomes (Ban et al. 2013; Chan et al. 2012; Kinzig et al. 2013; Redpath et al. 2013). While there are many studies of (rural) women and land use (Agarwal 2009; Radel 2012; Schwartz 2017), studies on the relationship between gender and PES are far from abundant. In recent years, articles have been published on gender and PES (e.g. Kariuki and Birner 2016; Schwartz 2017), but academic scholarship is far from establishing established relationships between gender and different forms of PES.

This article explores the effects of PES on women's livelihoods as a result of the different roles and responsibilities they hold at a community level. In order to do this, we employ a feminist political ecology approach, and we pay particular attention to gendered livelihoods and forest management. The Socialist Republic of Vietnam is chosen for this study as it is one of the pioneering countries for PES implementation (or more specifically, payment for forest environmental services - PFES), the Reducing Emissions from Deforestation and Forest Degradation program (REDD+), and community forestry (Bayrak 2019), but there is still a dearth of knowledge on the relationships between gender, livelihood and PES in the Socialist Republic (McElwee 2016; Haas et al. 2019).

In the sections that follow, gender and forest management, and gendered livelihoods are first explored through the existing literature. Here, we define concepts of feminist political ecology and gendered livelihoods. We then present the methodology and description of the research context. The results section deciphers the complex relationships between PES, livelihoods, forest management and participation from a feminist political ecological perspective. The final section is the discussion and conclusion, and we provide some policy recommendations.

\section{Literature review}

\section{Gendered livelihoods and the environment: a feminist political ecology perspective}

The ecological connection between gender and development has been explored extensively. One of the prevailing theories in this field is feminist political ecology (FPE). This critical approach looks at how gender relations are produced through language, culture and performance (Butler 1990), while being embedded in social, economic and cultural regimes of power in specific historic, ecological, geographical and political contexts (Rocheleau and Nirmal 2015). FPE highlights how gendered subjectivities, ideologies and identities are produced, contested, and employed around the governance of livelihoods and environments (Rocheleau et al. 1996; Di Chiro 2008; Harcourt 2017; Hovorka 2006).

The search for good living, secure livelihoods and the 'sustainability of life' with a focus on interdependencies between people and ecosystems is key to the FPE approach (Wichterich 2015). Harris (2015) concludes that sustaining livelihoods is about ensuring fundamental human requirements such as nutrition, ecological balance, clean water, secure housing, gender equality, and meaningful and diverse approaches to labor. She also states that an FPE approach to livelihoods mean more than simply examining and addressing economic needs and generating income, but is also about everyday interactions, embodiments and emotions (Harris 2015). FPE explores emotional and affective relations with our environments, and aims to understand the interaction between gender and environment (Harcourt and Nelson 2015).

Women's livelihoods are generally different three main ways compared to livelihoods of men, namely: control of income, resource use and production, and land rights (Radel 2012). Literature on gender and livelihoods has commonly examined social processes that shape household community-based economic 
strategies (Bebbington 2000; Francis 2000; Lipton 1996; Scoones 2009). Francis (2000) argues that livelihoods are often linked to control or power in society, which is influenced by gender, age, and other social identities or roles in households and communities. More specifically, gendered livelihood strategies are embedded in power relations in which women tend to have less control over income and expenditures for household and family needs (Bob 2000; King 2007; Oberhauser 2016).

Feminist analyses of livelihoods and natural resource also focus on gendered aspects of the reliance of households and communities on natural products as sources of income (McCusker and Oberhauser 2006; King 2011; Resureccion and Elmhirst 2012). Shackleton et al. (2008: 506) state: "...trade in natural products may be one of the few accessible local income generating options available to the rural poor, and women in particular." A trade in natural products provides additional options for income generation, allows households to diversify their income, provides a safety net for those facing shock and hardship (i.e. stressors), reduces reliance on other safety nets, and assists with meeting specific cash needs such as school fees (Shackleton et al. 2008). Moreover, Shackleton et al. (2008) argue that it also provides intangible benefits such as respect, new skills and social networks, flexibility, and more dignified ways of earning a living. Based on these previous studies, and through an FPE lens, we define gender-based or gendered livelihoods as: A way of living that comprises the capabilities, assets and activities required for ensuring fundamental human requirements, as well as the relationships and interactions with the environment, and how in each one of these livelihood dimensions differences arise between genders due to embedded power relationships in society.

\section{Gender and forest management}

To be able to assess the relationship between gender and forestry it is important to understand the different gendered factors in forest management. Gendered livelihoods and forest management together constitute the general forest-based livelihoods of women. Bini Agarwal has investigated gendered forest management through multiple studies (Agarwal 1992, 1997, 2000, 2001, 2009). Agarwal's studies show different instances where inefficiencies or problems arose due to a lack of women's participation and other factors. These factors are explored below. Even though her studies primarily focus on community forestry (CF), we argue that many of Agarwal's findings can also be applied to PES in Vietnam.

\section{Rule enforcement}

Lack of rule enforcement and rule violations can jeopardize the sustainability of CF and the projects related to it. In a case study by Agarwal (1997), women were the perpetrators of illegal forest exploitation for about $70-80 \%$ of the time. However, these violations tend to arise due to the discontent women have with formal rules on CF. They judge these rules, mostly imposed by committees dominated by men, as unfair. Violations could be a way to express resentment (Agarwal 1997; Shah and Shah 1995). Women often take up their own separate patches of forest, and in turn, violate the established rules (Agarwal 2000).

\section{Imperfection of information flows}

Connected to rule enforcement, information flows among all community members is crucial in enhancing the awareness levels and understanding of intricate rules regarding CF or PES. Information flows exist on different levels, such as household and community. Information on most forest management aspects, such as the rules, changes in rules, and membership eligibility, does not always trickle down to women. For instance, in a case study in West Bengal villages in India, only a small percentage of women were aware of these aspects of forest management, and there were even villages were none of the women were aware (Sarin 1998 in: Agarwal 2000). Similarly, officials seldom consult or inform women when creating micro-plans for forest development (Shah and Shah 1995). This lack of information towards women, or imperfection of information flows, leads to a majority of women not being able to participate in CF/PES, due to not knowing the current rules, and any shifts in these rules. 


\section{Inaccurate assessment of resource depletion}

Women and men can potentially enter different areas of a forest due to different preferences, or they assess certain forest products more accurately than others due to their own perceptions of the importance of the products (Agarwal 1997, 2009; Mwangi et al. 2011; Shiva 1989). Therefore, they perceive and assess resources differently, and exclusion of one group could consequently lead to inaccurate assessments of resource depletion or degradation within CF/PES projects. This could seriously jeopardize the success of these projects (Agarwal 2000).

\section{Protection against transgressors and conflict resolution}

Women tend to create their own patrol groups in the forests. As women are often not included in formal forest protection schemes, these groups are usually regarded as informal. The protection of forests is more successful when women's groups are involved, and they show a strong potential in effective forest management (Agarwal 2000). They help with information flows, they create awareness for the need to conserve forests, monitor forest use, and the groups exert social pressure on women who violate usage rules (Agarwal 2000; Chaudhuri 2013; Mwangi et al. 2011; Coleman and Mwangi 2013). However, being regarded as an informal group leads to some issues, as the perpetrators found by these groups often go unpunished due to their lack of authority. This also counts for other conflict resolution related issues.

Conflict resolution tends to be formally done through committees dominated by men (Agarwal 2000). This is illustrated in the previous example of a lack of punishment for transgressors caught by women's protection groups. Even when disputes directly involve women, they are often excluded from the conflict resolution meetings. This often entails that dispute or conflict settlements are very male-biased according to the women (Roy et al. 1993 in: Agarwal 2000; Coleman and Mwangi 2013).

\section{Gendered knowledge and preferences}

An important contribution of women to forest management is knowledge of different types of forest products, how certain forest products are extracted, what type of plants or trees should be planted, and general (indigenous) knowledge of the forest (Agarwal 2000; 2009; Shiva 1992). There is a gendered difference in knowledge of the forest and certain preferences in management (Shiva 1989, 1992). These differences in knowledge often result from the different activities and jobs that men and women perform. For instance, where women are seed collectors, they are considerably better informed about different seed varieties and relevant information on these seeds, much more so than men are (Burling 1963 in: Agarwal 2000; Shiva 1992; Shackleton et al. 2011). Furthermore, when women are collectors of firewood and other types of fuel from the forest, they are able to identify different trees species and their characteristics (Howard 2003; Shiva 1992; Shackleton et al. 2011). Generally, studies report some spatial differences in knowledge. It is expected, rightly or wrongly, that men are often better informed on tree species that reside in distant areas, while women have more knowledge on their immediate local environment (Agarwal 2000; Jewitt 2019).

\section{Research context and methodology}

\section{Research context}

Thuong Lo is an indigenous and mountainous commune in Thua Thien Hue province (Figure 1), consisting of three villages, and it is situated about $46 \mathrm{~km}$ away from Hue City. Thuong Lo's population was 1,409 in 2018 (Haas et al. 2019). It is located for a large part around and inside Bach Ma National Park, with the villages residing on the edge of the national park. Most people in Thuong Lo live from (forest-based) agriculture, with rice and cassava being the main crops (Figure 2a). The main village in which our interviews were conducted was Cha Mang village. Cha Mang consisted of 324 people in 82 households in 2018, of which 98 people were Kinh (the majority group in Vietnam) and 226 were Co Tu people (Haas et al. 2019). As Co Tu people are traditionally forest-dependent, Cha Mang village was purposively selected as the main study site. 
The organization of forest protection in Thuong Lo (and Vietnam) is more or less clearly defined. Forest Protection Divisions and Forest Development Divisions operate at both the provincial and district levels. They have specific tasks related to the protection and development of forest resources. These divisions relay the overall forest management strategy to the local communal government, which then implements it (Figure 2b). Community forest protection activities are conducted by so called forest protection groups. These groups are chosen by the local government, and are each assigned a schedule, protection area and associated (monitoring) tasks (Hoang 2016). Meetings are held at around four times a year in the communal longhouse (Figure 2c). During these meetings the planning of forest management, which includes the selection of participants and protected areas, coordination, and the handling of violations, is performed (Pham et al. 2016). The areas in which these activities take place are in the forest surrounding the village, which is situated about 30 minutes to an hour away from the village by motorbike, and entails both the fringes of the forest as well as areas further into the forest (Figure 2d).
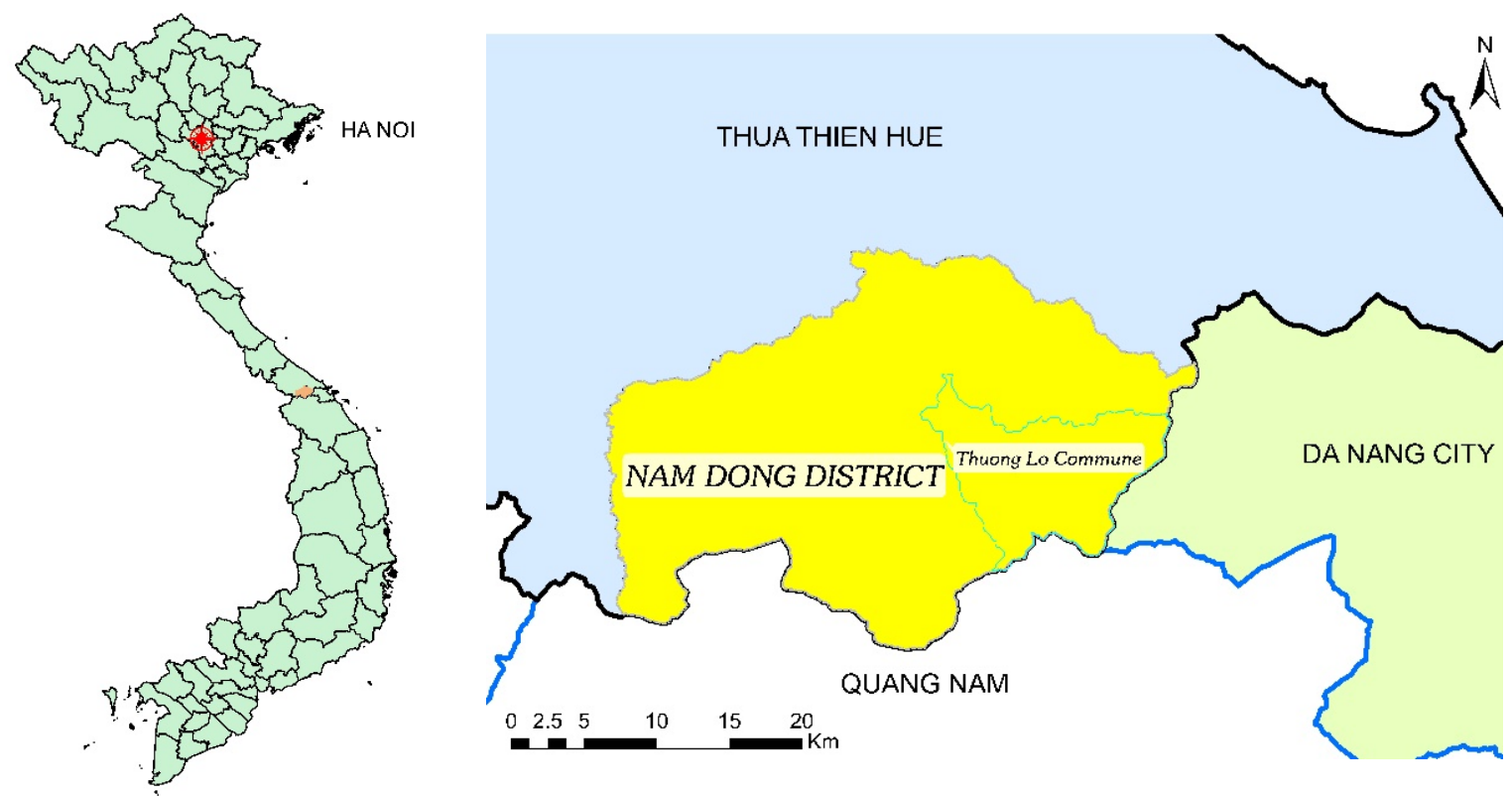

Figure 1: Local study site.

The commune hosts a multitude of organizations set up by locals and these organizations are often centered on a certain group or activity. For example, there is an organization for the elderly, an organization for forest management meetings (dominated by men), and a women's organization. In this instance the women's organization is of massive interest. This is a community of women that stresses rights of women and tries to promote participation in different activities such as forest protection. It holds representatives that attend important commune and village meetings and then pass on information to the other women. This organization is unaffiliated to any government agency and is an initiative by the local women themselves. Any woman of the local community is able to join, but there seems to be a hierarchy that came about naturally, where women who were married to higher officials of the local government represent and lead the organization. A majority of the women in the village attends these meetings. Moreover, the organization assists other women to cope with stressors (i.e. poverty, typhoon damage, flooding, etc.) through donations, both monetary and material, and it hosts information sessions on relevant activities in the village. 


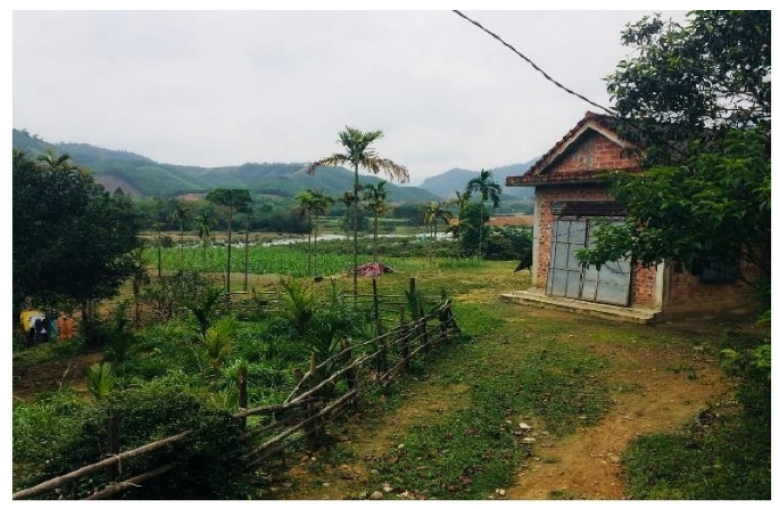

(a)

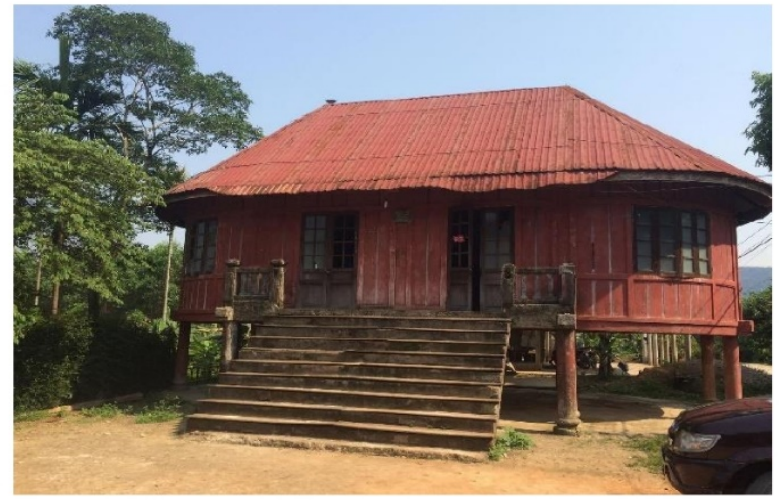

(c)

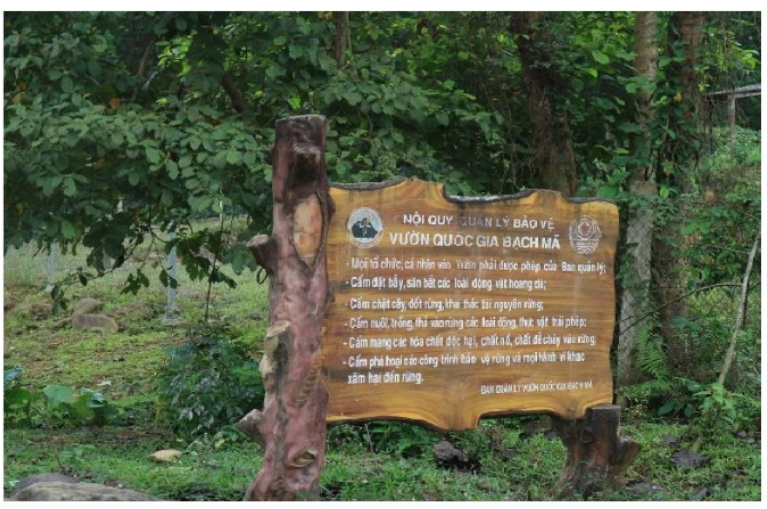

(b)

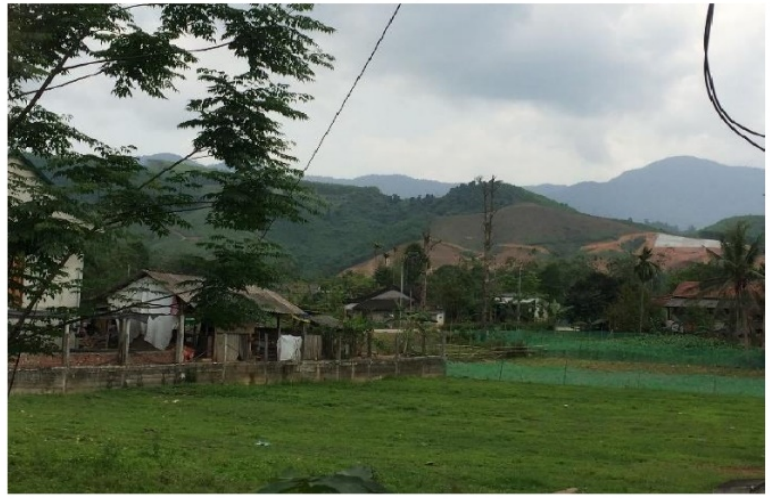

(d)

Figure 2: Agriculture in Cha Mang. (a); Forest conversation rules outlined by Bach Ma National Park (b); Communal longhouse of Cha Mang (c); and (d) Landscape of Cha Mang with in the background, natural forests.

\section{Methods}

This study adopted a qualitative approach, and the methods were as follows: observations, unstructured in-depth interviews, and focus group discussions. Moreover, local reports and data were gathered from the main commune (sub-district level unit) and village offices (Hoang 2016; Truong and Truong 2016) in order to triangulate our findings and to provide background information on the study site. We adopted a qualitative approach in order to understand the intricacies of women's livelihoods, their relationship with the environment, and their thoughts and perceptions on forest management and PES. However, we realize that as we did not adopt an ethnographic approach (due to time constraints) and also due to our own positionality, we do not claim to fully understand these complex issues. Hence, the goal of this study was to provide some important insights into gendered livelihoods and forest management in the context of PES in Vietnam.

The research was carried out in Thuong Lo commune, Nam Dong district, Central Vietnam. We have conducted research in the study area (or in close proximity to the study area) for almost a decade now (e.g. Phuc et al. 2011; Bayrak et al. 2013; Tinh and The 2013), and we were therefore able to embed the results of this study in the wider socio-economic, temporal and ecological context.

The period of research was about three months in 2018. The majority of interviewees are indigenous Co Tu people, as the Co Tu traditionally portray activities in forest management and protection (Bayrak et al. 2013). Both men and women were interviewed to be able to assess the differences between the groups. Purposive sampling along with snowball sampling was used to garner participants. Through a local guide, we adopted a purposive sampling approach. Snowball sampling was used during instances where interviewees 
would voluntarily assist in finding other relevant interviewees. The combination of these sampling techniques through both a local guide and the interviewees allowed us to interview people that would otherwise be potentially unreachable. Through specific purposive sampling a diverse sampling group in terms of age, gender, ethnicity, and social status was realized. Furthermore, this allowed us to specifically approach people who we knew were relevant for our research. This resulted in thirty extensive interviews, accompanied with two focus group discussions. The interviewees were seventeen women and thirteen men, of which 25 interviewees were Co Tu, while five were of Kinh ethnicity.

Several (practical) limitations were associated with our employed methods. Using an interpreter resulted in data loss through translation barriers. A local Co Tu language interpreter was also occasionally present since older Co Tu were sometimes unable to speak fluent Vietnamese. Certain people were unavailable during the timeslots in which we were able to do our interviews. We also faced the impossible task of completely understanding the intricacies of the local community, which could lead to researcher bias, especially in our observational results. Although some of these limitations were inevitable, the strengths of this research assured a valid gathering of data. A great diversity of people (gender, age, income, ethnicity, etc.) were interviewed. During the research we had full access to every household by having the local community leaders guide us through the village. Furthermore, the usage of both qualitative and participatory methods limited the weaknesses of each individual method.

\section{Results}

\section{Gendered livelihoods and income management}

In this section we explore the differences found in livelihoods through a gendered lens. The livelihoods of women in Thuong Lo posed a major issue. They are (most often) unable to gain a significant income, as the income is attributed to the husband of the household. When mentioning income and monetary gains, women tend to speak about the household level, since the husband controls the income and money of the household. Thus, tangible and monetary livelihood gains have always coincided with the livelihood increase of the entire household. Women that contribute to forest protection do not gain an income directly, as the majority of this money is paid to the husband. Women's own valued ways of being and doing can be constrained due to not having enough monetary gains to achieve their own goals, depending on how the husband regulates the household finances.

It should not be any surprise then that women have adopted livelihood strategies that increase the portfolio on a household level as their involvement in the women's organization and other jobs are able to generate income. Occasionally, the women's organization would donate either monetary gifts (ranging around 300,000 VND or US\$12.63) or items (such as food) to women in struggling households in the community as a means for these households to cope with stressors such as storms and flooding. Thus, women tend to adopt livelihood strategies at an organizational and individual level, which affects both community and household livelihoods. Men, on the other hand, have the ability to diversify their livelihoods at both an individual and household level due to their access to resources, both monetary and social. They have developed different coping strategies towards natural hazards and events. Moreover, they more often express an interest in doing freelance work for others, to increase their income. They are also able to gain an income from forest protection including PES, although this monetary stream was regarded as relatively small by our interviewees.

\section{Resource use}

As discussed in our definition of gendered livelihoods, livelihoods also compromise the emotions and the human relationship towards the surrounding environment, the forest in this case. The dissonance between genders on this seems to influence resource usage and agricultural activities. In terms of forest agriculture, the differences are distinct. Women participants of the study were often found to be against the intensification of agriculture. Women in Cha Mang village display a preference towards the usage of different crops, such as banana, cassava, and jackfruit, whereas men generally portray a preference towards plantation trees such as acacia (A. mangium and A. auriculiformis) and rubber trees (Hevea brasiliensis). The latter's reason for 
preferring this strategy is that the monetary gains from these cash crops would mitigate or compensate for any livelihood loss made from monoculture agriculture. This has some link to environmental attitudes, as women often suggested that forests were of great importance to many fellow members of the community, and that these communal interests should be taken at heart. Men often disregarded this issue, and instead preferred current forest management rules that allowed for commercial forestry activities to occur.

\section{Production and land rights}

It is nearly impossible for me to have any sort of say into usage of land for production and protection activities. The government allocates plots of land to households through Red Books [certificate of land ownership]. These are registered in my husband's name. Protected areas are also allocated and determined by a government committee dominated by men.

This quote from a local woman illustrates the issues concerning land exploitation and rights in the community. Land is distributed by the local government to the men, for both conservation and livelihoods. This allows the men to have the opportunity to, for example, determine what resources will be produced, and what areas need to be protected. Moreover, since the Red Book ensures that men have the legal status of ownership of their household land, any income from agricultural activities is under the man's name as well. There were a few cases where men who own the Red Book would share responsibility and gains from production and protection activities with their partners, but the fact remains that the men of the community have first say in all the relevant activities and gains from land exploitation and protection.

Due to a lack of land rights, the agricultural production and resource exploitation of women is often based on NTFPs or other forest products. However, forest areas, in which the collection of NTFPs is allowed, is allocated and regulated by the local government since they are responsible for forest protection. Consequently, women felt constrained in collecting NTFPs due to rules generated by committees mainly dominated by men. This leads to issues such as this quote by a local woman:

We have less land to use during our collection activities in the forest, the rules are restricting our activities and resources that we can gather, women are earning less money due to this, as the collection of forest products was one of our ways to gain direct income.

Overall, women lack the ability to gain any monetary income from their household's land, since this is registered in the man's name, while they are also constrained in their ability to collect or harvest their preferred products from the forest. This resulted in a (direct) loss of income for the women.

\section{Relationship with the environment}

Preferred activities that allow people to interact with the environment in their preferred manner allows them to achieve, as Sen calls it, valued ways of being and doing (Sen 2001). Activities in forest management is a salient issue for many of these local women. They often speak of the forest as: "their home" and realize the importance of the forest to fellow community members whose livelihoods are still forest-dependent. This dependence on the forest is often traditionally associated with the collection of NTFPs, such as firewood, herbs and other smaller plants. Women were often quoted as being the main collectors of these products. These local women have their own preferred forest products and areas that need to be protected, and were therefore very willing to be active in forest management. Moreover, this specialization of NTFP gathering has provided them with knowledge on certain forest products that the men of the community do not necessarily possess.

The following two quotes illustrate the differences between genders on their views on PES and forest protection accurately, with a woman illustrating the general view of women in the village: 
The forest is the garden or crops of many inhabitants of the village. It is very important to care and tend for it, and it is important to keep criticizing and seeing new opportunities to make the management better. There is no reason to be satisfied with current rules.

While the view of men can often be illustrated with this quote (by a male interviewee):

I have no complaints on how forest management is done, it is not a job, but it is our responsibility to care for the forest. Therefore, we should follow the plan created by the community forest management board.

The responsibility for participation lies at the household level, which means that, through social standards, forest protection and management are almost completely performed by men. This is underlined by the following statement by Cha Mang's village headman:

Only one person per family is allowed to come [to village meetings on forest protection], that is why often the men of the household go and women do not attend. When the man of the household cannot come, another representative of the household will come, these are often sons or other delegates of the household, it is usually not a woman that comes, as forest protection is considered too dangerous to them.

Thus, actual responsibility to participate in forest management is given to men, as the acknowledgement of social norms by the village headman illustrates that the local government realizes that women would not be present. Therefore, the usage of the word household responsibility can be seen as an arbitrary term, as it is assumed that it is the man who participates. In general, even if they have a low responsibility for (formal) forest protection, women tend to show a desire to participate and change certain processes of forest protection, due to their relationship with their environment, and their opinions on how to preserve it. This is often substantially different from their male counterparts. Moreover, the differences in gendered livelihoods are apparent in other areas as well, such as control of income, land rights and production, and resource use.

\section{Effects of PES on gendered livelihoods}

Having discussed the differences in livelihoods between the two groups, we now provide an assessment of how PES affects the livelihoods of women. Firstly, PES and forest regulation affect the gathering, production and usage and of certain forest products. Women often stated that, due to these forest protection regulations, they were unable to gather certain products, such as cassava, that they harvested in previous years. Therefore, women are forced to either switch to crops that are available to plant, such as the cash crops, or collect NTFPs and other forest products in different areas of the forest. This brings new difficulties, as these areas are often located further away from the village. This could seriously disrupt women's daily schedules, which could force them to neglect their other (livelihood) activities. In some instances, women asserted that they are unable to attend important meetings now, including their women's organization, which could be of benefit to their livelihood security.

Women's livelihoods, and in turn household livelihoods were, in some cases, affected by these restrictions on forest use in relation to income. As stated, there are still many households that are dependent on forest resources. Women lost income from the forest, and they were unable to raise cash through new means, when they lacked cash to diversify their livelihood strategies. In some cases, this led to violations of forest regulations, as women had to continue gathering in restricted areas. There were reported cases of women and their households being ostracized due to violating forest regulations. These women did this as they claimed to be dependent on forest products and could therefore not adhere to the formal rules. There were also instances where women feared for their husbands' safety, due to their work in forest protection. Their husbands were sometimes forced to conceal any incidents in the forest or otherwise face the risk of being ostracized or 
punished by the violators. Both instances created stress for the women, but there were also households being cut off from others in the community and, consequently, losing their support network during times of crisis.

Therefore, PES affect livelihoods of women on both sides of the coin, forest dependent women, but also women who are part of households that are active in forest protection. However, these tangible effects of PES are not the only dimensions affecting women's livelihoods. Their everyday interactions and emotions concerning their surrounding environment are affected as well. Women were often quoted to have strong feelings of anger or disappointment when discussing their social exclusion from forest protection. In their eyes, the forest is as much their home, as it is the home of the men of the community. They felt that they are not being considered as relevant in formal forest protection, despite many of their activities being important to forest management (e.g. NTFPs collection, and policy discussions during meetings of the women's organization). Through the women's organization they were able to mitigate some of their disappointments. They could address local forest protection leaders through the women's organization, and also address (forestrelated) issues that they felt had to be tackled. Nevertheless, the women's organization leaders proclaimed that they did not have the ability to do this extensively, as they met with government officials just once or twice a year. They felt somewhat disconnected from the forest as they were often excluded from contemporary management issues, even though traditionally they were most active in this area.

PES influences women's livelihoods on many dimensions: from forgone income to their personal relationship with the forest. Perhaps greater inclusion of women in forest management and protection could mitigate these effects, or even enhance their livelihoods. To assess this, the next section deals with gendered forest management, and how these differences in turn could affect PES and the effects of PES on livelihoods.

\section{Gendered forest management and PES}

First of all, a common heard critique by women of the community was the effects that the new PES rules had on their ability to collect or harvest NTFPs, crops and other forest products. Interviewees stated that it affected their income and their ability to use these products for their own livelihoods. Moreover, it was often stated that some community members are still very dependent on the forest, and that they are unfairly affected and treated by these rules. An often-heard suggestion from women was to enact policies for people heavily affected by forest management rules. Some mentioned compensation, special treatment and even that the government should provide jobs or other forms of income for the forest-dependent inhabitants. A sharp contrast can be seen among men; they are often very content with current rules, and do not wish to or do not feel like criticizing the community forest management (CFM) and PES schemes implemented by the government.

Women rarely attend forest management meetings, as stated before, and only occasionally hear about the rules through their husbands or other participants in forest protection. This results in incomplete information sharing with the women. However, women have created other channels through which they receive information on the rules of CFM and/or PES. The women's organization sends delegates to CFM meetings; in turn, these delegates relay the information on CFM/PES to members of the women's organization during their periodic meetings. Most women were part of the CFM organization and therefore had access to the rules and enforcement processes set up by the forest management board. The extent to which this information is as complete as the information that men active in forest management receive is difficult to assess. Thus, the critique of rules and enforcement can both arise from a lack of information on the side of women, or due to the difference in definition of what PES is and should be. A well-negotiated set of rules, created by a discussion between both genders could potentially lead to greater compliance and effective management of the forest. Hence information asymmetries between the genders remain an important issue.

We found that women who solely received their information from their husband or male relatives, and not through the women's organization, displayed a lack of knowledge on details of the rules, income, actions and other processes in relation to PES. These women often yearned for more information on PES, for instance, through local organizations coming to the households themselves to explain it to the entire household, instead of only the husband. Their lack of knowledge on the details of PES was often illustrated when discussing issues such as income gained from forest protection, the precise areas under protection, and which forest species were subject to protection. Testing their knowledge, most interviewees gave a range of answers on these questions 
of income, boundaries and protected species of plants, animals and herbs. In contrast, male interviewees, all participating in PES, provided us with similar answers throughout. Women that are part of the local women's organization, which attends every forest protection meeting through delegates, understood the official process on dealing with violators in the community forest area, what income people should legally receive, and often clarified what species of plants, trees and animals are protected and in which areas. This shows the value of participation in meetings and decision making for grasping the true nature of PES, and the process associated with it.

Inaccurate assessment of resources is an issue that arose while talking to women. Due to their different preferences for forest products, they feel that major forest areas are being neglected in protection duties. The preference for high-income products by men leads to a focus on the tree species of the forest, such as acacia, rubber and timber-providing trees. Men and women assessed the value of individual species differently, which could potentially result in inaccurate resource assessments. When excluding women, smaller NTFPs are often excluded from accurate assessment, while protection groups solely consisting of men protect high-income trees by preference. Differences in preferences do not only affect how protection activities are carried out, but also what equipment should be used, and how people are protected against violators or transgressors.

Most men interviewed in Thuong Lo held the view that women should not participate in forest protection as it is too dangerous. There are potential risks from unknown male perpetrators, while working in isolated places. However, this stereotypical view is without foundation. According to an interview with a local community leader, there have been almost no reported problems in the last couple of years. Men also acknowledge that there weren't violations or transgressors and they are generally content with their ability to apprehend aggressors when it is necessary. The variance of views that exists here is not based on material vulnerabilities, but with the assessment of them. Many women interviewees actually expressed their concerns for their husbands during their forest protection duties, as there have been unofficial (non-reported) cases of assault by people from outside communities. This was something not mentioned by men who we interviewed. Women also stressed that forest protectors have nothing to defend themselves with should such instances arise, while men would rarely comment on this. Male interviewees only stressed the dangers of forest protection work for women, thus cementing their position as guardians and the implementers of PES regulations.

\section{Importance of women's participation: participation and direct benefits}

During the small instances where women do forest protection work, the PES (and future REDD+) payments go through their husband. This payment often ranges around 100,000 VND (US\$4.21) for a day of forest monitoring. But because most of them can't work in formal forest protection, they do so on an informal or voluntary basis and these payments are rare. The question remains, however, whether any compensation received from forest protection is significantly contributing to poverty reduction in the village. The answer is negative according to all the respondents. The compensation is far too low according to many women. Men, on the other hand, do not necessarily stress the issue of insufficient compensation, but merely acknowledge that the money does not provide sufficient income for them and their families. Participation of women in PES is unlikely to change policies that affect women's livelihoods in relation to forest products and income. These policies are heavily dependent on the command-and-control structure implemented by the Vietnamese government. This way of conducting government affairs defines how payments and other livelihood benefits are distributed. Therefore, as long as this command and control structure is in place, women are highly unlikely to financially benefit from PES.

Thus, income from forest protection has no effect on reducing poverty in Cha Mang village, and the policies responsible for this are unlikely to change. However, there are other nonmaterial benefits that can arise from participation. This includes women's empowerment and overall well-being.

\section{Participation and empowerment}

Everyone in the community perceives forest protection as a massively important duty. Enabling women to participate would allow them to gain recognition in terms of being able to do a job that is considered 'too 
dangerous' for them, as well as possessing an important responsibility for the community. The importance of this is illustrated by a local Co Tu woman:

The importance of protecting the forest is great, it provides us with food, building materials, protects us against environmental stressors and is most of all, the place we live, it is our home.

As we mentioned, a few women are occasionally invited to participate by other forest protectors, usually men, showing recognition that they are able to sufficiently perform this activity. Eventually, the extension of inclusiveness could tackle the existing social norms of local forest management and its patriarchal nature. Women seeking participation could, as they told us during our interviews, also increase their skills and capacities, learning more about forest-related issues and different ways of forest management.

In addition, more participation has the ability to influence the agency of women and social norms. Those few already at work in forest protection have already changed social norms to a slight extent, by making a good impression with men. Further change will occur if more and more women are able to participate in PES and forest protection activities. But social norms on income distribution also need to become more gender sensitive, and only this will result in personal resource empowerment.

\section{Participation and well-being}

Gender inclusion in forest protection emerged as an attribute of well-being, improving social status and social standing in the community in a situation where wealth and power is constrained by social norms. Inclusion in PES, has the potential, albeit low, to alter wealth through a multitude of factors that need to be changed, both at the local and national level, as explained above. The agency of women could also increase due to the recognition of the potential of women in forest management and PES. Furthermore, inclusion of women allows for a creation of a bigger network and a strengthening of already existing social ties. Thus, participating in forest management and PES could create new (types of) relationships with government actors and other stakeholders. To illustrate this, one of our interviewees, the wife of one of the local officials on forest protection, stated that:

I am personally a part of a small group of women participating in forest management, as a group we are now able to exert pressure towards forest management officials through our husbands, and we are able to voice our concerns over general issues in the community as well.

This new but growing group of women was able to use their individual ties to exert pressure on local government officials by acting as representatives of the local women in the community. During meetings, they put issues related to forest management and other general concerns on the agenda, which the women deemed as important. Agency, an important aspect of well-being, was thus increased through different types of ties that were gained through inclusion in forest management and PES. Therefore, PES inclusion is investment in social capital in and of itself, through creation of new networks and ties, and the strengthening of such ties.

\section{Discussion and conclusion}

Scholarship on PES and gender inclusion is far from established. Studies that do combine the two aspects together often focus on the negative outcomes of PES (or REDD+) projects for women, and not necessarily the potential that women have when participating in such projects (Brown 2011; Larson et al. 2015). Understanding the relation between PES and gender requires a full understanding of gender empowerment, livelihoods and forest management. This article strengthens the evidence, as illustrated by Muradian et al. (2010), that PES frameworks should embrace the socio-cultural and behavioral implications of the commodification of nature in greater depth (Bowles 2008; and see also Escobar 1996). Social conditions, and gender equality, enable or hinder PES effectiveness (Muradian et al. 2010). This in turn illustrates the importance of using a feminist political ecology approach, to elucidate how women are affected differently by 
PES due to prevailing social-cultural conditions and power relations. Women also have the ability to influence PES positively through their own preferences and knowledge, assisting forest management as well as addressing gendered livelihood requirements. A feminist political ecology of PES explores the underlying conditions and driving factors behind PES performance as well as the socio-cultural implications of such (neoliberal) projects.

In Vietnam, sedentarization policies, mass migration of Kinh farmers to the highlands, the transition to a 'socialist' economy, forestland allocation ${ }^{2}$ as a means to restructure (indigenous) space, and now formal forest protection through CFM and PES, are all important historical examples of macro-level policies. Gradually, local and indigenous communities have been integrated into the market economy through the commodification of nature and the introduction of commercial forestry and agriculture (Bayrak et al. 2013; Bayrak 2019; McElwee 2016). It is important to investigate how gendered livelihoods and forest management practices looked like prior to the implementation of macro-level government policies and governmental influence. In the case of the Co Tu people, an ethnographic study by Arhem (2010) shows how women were expert hunters, fisherwomen, and farmers, and it extensively describes the rituals both men and women had to perform prior to hunting, collecting forest products, and farming. These past experiences are important to understand the knowledge women and men have and their current gendered preferences towards and perceptions of PES, and forest management more generally. The effects of PES on gendered livelihoods and forest management have not been equal as we have shown, but more studies are needed to investigate how these macro-level policies interact and restructure gender roles in local and indigenous communities in Vietnam, and beyond (Haas et al. 2019).

In this article, we argue that more research should focus on exploring the complex relationships between gender and PES, as well as other neoliberal or payment-based forest protection programs. But "the ecosystem services approach is often blind to the wider institutional context in which services are situated" (Menon and Rai 2019: 655). Moreover, this study illustrates the constraints that macro-level factors or policies have on the potential for women's participation in forest management and PES. Gender inclusion shows potential in effective forest management, and the further empowerment of women in Thuong Lo. The effects of PES on the livelihoods of women were found to be more ambiguous. In terms of non-monetary benefits, a relationship between gender inclusion and women's empowerment was perceived, both in terms of social resources, human agency and achievements. However, its lack of effect on material, or monetary, resources was unexpected, as the previous literature would suggest such a relationship (Agarwal 1992). The constraints that were illustrated in our literature review, arising from the command and control structure of Vietnamese implementation of PES, proved to be altering the potential of women's participation. This has resulted in a lack of participation of women till this day, and in turn results in a less conclusive illustration of the potential of gender inclusion. On a more positive note, local social norms have been shown to shift ever so slightly, allowing for more participation of women to occur in forest management, CFM and PES.

The findings provide some important policy recommendations. PES policies in Vietnam should recognize the gender potential portrayed by the local women in the community as well as the potential of local women's organizations. However, policymakers should also recognize that macro-level policies (e.g. the command and control structure) in Vietnam constrain or bind the potential of women in PES and forest management. It is furthermore recommended that gender empowerment and inclusion, where necessary, should be a major aspect of PES policy creation. To tap into the full potential of women's participation, local social norms would have to change further, while the Vietnamese government should specifically address genderrelated issues and potential in their policies concerning forest management and PES.

The Co Tu men in our study perceive forest protection to be their responsibility. But the whole community sees the forest as their home, and it means much more to them than one could imagine, as Arnhem describes it: "The Katu [Co Tu] know every stream, hill and trail of their land. What might seem to an outsider as "just a forest" is something infinitely more to the Katu; every place has a story to tell, known to each and

\footnotetext{
2 The Forest Land Allocation program (FLA) in Vietnam was introduced in 1991. The official logic was that "allocating forest land to individual households, household groups, or communities for fifty years would be beneficial for forest preservation and restoring forest cover and increasing biodiversity" (Bayrak, Tran and Burgers 2013: 37).
} 
every villager" (Arhem 2010: 189). It is thus of major importance for the Co Tu people to protect their forest as effectively as they can. We argue that this can only be achieved by allowing women to participate fully in this process. Recently, a rise in participation has occurred but much more is needed to allow women to protect what they consider their home. PES policymakers need to understand the untapped potential that gender inclusion represents in not only aiming for effective forest protection, but also for gendered empowerment. New PES schemes should be created in cooperation with all members of the community (not only women but also other minorities, such as sexual minorities, the elderly, other ethnic and local groups, people with disabilities, etc.), and gender empowerment should be taken as one of its main starting points. We believe that this could assist the indigenous $\mathrm{Co} \mathrm{Tu}$ (and other local and indigenous communities) to truly protect their home: the forest.

\section{References}

Agarwal, B. 1992. The gender and environment debate: lessons from India. Feminist Studies 18(1): 119-158.

Agarwal, B. 1997. Bargaining and gender relations: within and beyond the household. Feminist Economics 3(1): 1-51.

Agarwal, B. 2000. Conceptualising environmental collective action: why gender matters. Cambridge Journal of Economics 24(3): 283-310.

Agarwal, B. 2001. Participatory exclusions, community forestry, and gender: an analysis for South Asia and a conceptual framework. World Development 29(10): 1623-1648.

Agarwal, B. 2009. Gender and forest conservation: the impact of women's participation in community forest governance. Ecological Economics 68(11): 2785-2799.

Arhem, N. 2010. In the sacred forest: landscape, livelihood and spirit beliefs among the Katu of Vietnam. Göteborg: Göteborg University.

Ban, N.C., M. Mills, J. Tam, C.C. Hicks, S. Klain, N. Stoeckl, M.C. Bottrill, J. Levine, R.L. Pressey, T. Satterfield and K.M. Chan. 2013. A social-ecological approach to conservation planning: embedding social considerations. Frontiers in Ecology and the Environment 11(4): 194-202.

Bayon, R. 2004. Making environmental markets work: lessons from early experience with sulfur, carbon, wetlands, and other related markets. Washington D.C.: Forest Trends. Available online: https://vtechworks.lib.vt.edu/handle/10919/66848

Bayrak, M.M. 2019. State of forest governance in Vietnam: where are the local communities? In H. James (ed.). Population, development and the environment - challenges to achieving the Sustainable Development Goals in Asia Pacific. Basingstoke: Palgrave Macmillan. Pp 273-295.

Bayrak, M.M., T.N. Tran and P. Burgers. 2013. Restructuring space in the name of development: the sociocultural impact of the Forest Land Allocation Program on the indigenous Co Tu people in Central Vietnam. Journal of Political Ecology 20: 37-52.

Bebbington, A. 2000. Reencountering development: livelihood transitions and place transformations in the Andes. Annals of the Association of American Geographers 90(3): 495-520.

Bob, U. 2000. Gender, the role of the chieftaincy and rural women's access to land under the land reform programme in KwaZulu-Natal. Alternation 7(2): 48-66.

Bowles, S. 2008. Policies designed for self-interested citizens may undermine 'the moral sentiments': Evidence from economic experiments. Science 320: 1605-1609.

Brown, H.C.P. 2011. Gender, climate change and REDD+ in the Congo Basin forests of Central Africa. International Forestry Review 13(2): 163-176. Available online: https://www.cifor.org/library/3534/

Burling, R. 1963. Rengsanggri: family and kinship in a Garo village. Philadelphia: University of Pennsylvania Press.

Butler, J. 1990. Gender trouble: Feminism and the subversion of identity. New York: Routledge.

Chan, K.M.A, A.D. Guerry, P. Balvanera, S. Klain, T. Satterfield, X. Basurto, A. Bostrom, R. Chuenpagdee, R. Gould, B.S. Halpern, N. Hannahs, J Levine, B. Norton, M. Ruckelshaus, R. Russell, J. Tam and U. 
Woodside. 2012. Where are cultural and social in ecosystem services? A framework for constructive engagement. BioScience 62(8): 744-756.

Chaudhuri. T. 2013. From policing to 'social fencing': shifting moral economies of biodiversity conservation in a South Indian Tiger Reserve . Journal of Political Ecology 20: 376-394.

Coleman, E.A. and E. Mwangi. 2013. Women's participation in forest management: a cross-country analysis. Global Environmental Change 23(1): 193-205.

Di Chiro, G. 2008. Living environmentalisms: coalition politics, social reproduction, and environmental justice. Environmental Politics 17(2): 276-298.

Escobar, A. 1996. Construction nature: elements for a post-structuralist political ecology. Futures 28(4): 325343.

Escobar, A. 1998. Whose knowledge, whose nature? Biodiversity, conservation, and the political ecology of social movements. Journal of Political Ecology 5: 53-82.

Francis, E. 2000. Making a living: changing livelihoods in Rural Africa. London: Routledge.

Gómez-Baggethun, E., R. De Groot, P.L. Lomas and C. Montes. 2010. The history of ecosystem services in economic theory and practice: from early notions to markets and payment schemes. Ecological Economics 69(6): 1209-1218.

Haas, J.H., L. Loft and T.T. Pham. 2019. How fair can incentive-based conservation get? The interdependence of distributional and contextual equity in Vietnam's payments for Forest Environmental Services program. Ecological Economics 160: 205-214.

Harcourt, W. 2017. Gender and sustainable livelihoods: linking gendered experiences of environment, community and self. Agriculture and Human Values 34: 1007-1019.

Harcourt, W. and I.L. Nelson (eds.). 2015. Practicing feminist political ecologies: moving beyond the "green economy." London: Zed.

Harris, L.M. 2015. Hegemonic water and rethinking natures otherwise. In W. Harcourt and I.L. Nelson (eds.). Practicing feminist political ecologies: moving beyond the "green economy." London: Zed. Pp. 157181.

Hoang, V.C. 2016. Danh sách cán bộ tham gia kiểm tra lấn chiếm, do dạc lập bản tại hiện truòng [List of participants for forest protection] Unpublished report. Thuong Lo: Thuong Lo Commune Government Vietnam.

Hovorka, A.J. 2006. The No. 1 ladies' poultry farm: a feminist political ecology of urban agriculture in Botswana. Gender, Place and Culture 13(3): 207-225.

Howard, P. 2003. The major importance of 'minor' resources: women and plant biodiversity. Gatekeeper 112. London: International Institute for Environment and Development.

Jewitt, S. 2019. Environment, knowledge and gender: local development in India's Jharkhand. London: Routledge.

Kariuki, J. and R. Birner, 2016. Are market-based conservation schemes gender-blind? a qualitative study of three cases from Kenya. Society and Natural Resources 29(4): 432-447.

King, B.H. 2007. Developing KaNgwane: geographies of segregation and integration in the New South Africa. The Geographical Journal 173(1): 13-25.

King, B.H. 2011. Spatialising livelihoods: resource access and livelihood spaces in South Africa. Transactions of the Institute of British Geographers 36(2): 297-313.

Kinzig, A.P., P.R. Ehrlich, L.J. Alston, K. Arrow, S. Barrett, T.G. Buchman, G.C. Daily, B. Levin, S. Levin, M. Oppenheimer, E. Ostrom and D. Saari. 2013. Social norms and global environmental challenges: The complex interaction of behaviors, values, and policy. BioScience 63(3): 164-175.

Kumar, P. (ed.). 2010. The economics of ecosystems and biodiversity: ecological and economic foundations. London: Earthscan. 
Larson, A.M., T. Dokken, A.E. Duchelle, S. Atmadja, I.A.P. Resosudarmo, P. Cronkleton, M. Cromberg, W. Sunderlin, A. Awono and G. Selaya. 2015. The role of women in early REDD+ implementation: lessons for future engagement. International Forestry Review 17(1): 43-65.

Lipton, M. (ed.). 1996. Land, labour and livelihoods in rural South Africa (Vol 1). Durban: University of Natal, Indicator Press.

McCusker, B. and A.M. Oberhauser. 2006. An assessment of women's access to natural resources through communal projects in South Africa. GeoJournal 66: 325-339.

McElwee, P.D. 2016. Forests are gold: trees, people and environmental rule in Vietnam. Seattle: University of Washington Press.

Menon, A. and N. Rai. 2019. The mismeasure of nature: the political ecology of economic valuation of Tiger Reserves in India. Journal of Political Ecology 26: 652-665.

Muradian, R., E. Corbera, U. Pascual, N. Kosoy and P.H. May. 2010. Reconciling theory and practice: An alternative conceptual framework for understanding payments for environmental services. Ecological Economics 69(6): 1202-1208.

Mwangi, E., R. Meinzen-Dick and Y. Sun. 2011. Gender and sustainable forest management in East Africa and Latin America. Ecology and Society: 16(1): 17.

Nightingale, A. 2002. Participating or just sitting in? The dynamics of gender and caste in community forestry. Journal of Forest and Livelihood 2(1): 17-24.

Oberhauser, A.M. 2016. (Re)constructing rural-urban spaces: gendered livelihoods, migration, and natural resources in South Africa. GeoJournal 81(3): 489-502.

Pham, T.T., K. Bennett, T.P. Vu, J. Brunner, N.D. Le and D.T. Nguyen. 2013. Payments for forest environmental services in Vietnam: from policy to practice. Bogor: Center for International Forestry Research (CIFOR). Available online: https://www.cifor.org/library/4247/

Pham, T.T., G.Y. Wong, N.D. Le and M. Brockhaus. 2016. The distribution of payment for forest environmental services (PFES) in Vietnam: research evidence to inform payment guidelines. CIFOR Occasional Paper 163. Bogor: Center for International Forestry Research (CIFOR). Available online: https://www.cifor.org/library/6297/

Phuc, N.Q., T.V. Hoa, P.X. Hung and P.T.T. Tam. 2011. Competitive ability of agricultural products in Central Vietnam: a case study of rubber products in Thua Thien Hue Province. Hue University Journal of Science 68(5): 99-108.

Phuc, X.T., W.H. Dressler, S. Mahanty, T.T. Pham and C. Zingerli. 2012. The prospects for payment for ecosystem services (PES) in Vietnam: A look at three payment schemes. Human Ecology 40(2): 237249.

Radel, C. 2012. Gendered livelihoods and the politics of socio-environmental identity: women's participation in conservation projects in Calakmul, Mexico. Gender, Place and Culture 19(1): 61-82.

Redpath, S.M., J. Young, A. Evely, W.M Adams, W.J. Sutherland, A. Whitehouse, A. Amar, R.A. Lambert, J.D. Linnell, A. Watt and R.J. Gutierrez. 2013. Understanding and managing conservation conflicts. Trends in Ecology and Evolution 28(2): 100-109.

Resureccion, B.P. and R. Elmhirst (eds.). 2012. Gender and natural resource management: livelihoods, mobility and interventions. London: Earthscan.

Rocheleau, D. and P. Nirmal. 2015. Feminist political ecologies: grounded, networked and rooted on Earth. In R. Baksh and W. Harcourt (eds.). The Oxford handbook of transnational feminist movements. Oxford: Oxford University Press. Pp. 793-814.

Rocheleau, D., B. Thomas-Slayter and E. Wangari (eds.). 1996. Feminist political ecology: global issues and local experiences. London: Routledge.

Roy, S.B., R. Mukherjee, D.S Roy, P. Bhattacharya and R.K Bhadra. 1993. Profile of forest protection committees of Sarugarh Range, North Bengal. IBRAD Working Paper No 16. Calcutta: Indian Institute of Bio-Social Research and Development. 
Sarin, M. 1998. Who is gaining? Who is losing? Gender and equality concerns in joint forest management. New Delhi: Society for Promotion of Wasteland Development.

Schwartz, G.J. 2017. The role of women in payment for environmental services programs in Osa, Costa Rica. Gender, Place and Culture 24(6): 890-910.

Scoones, I. 2009. Livelihoods perspectives and rural development. The Journal of Peasant Studies 36(1): 17196.

Sen, A. 2001. Development as freedom. Oxford: Oxford University Press.

Shackleton, S., B. Campbell, H. Lotz-Sisitka and C. Shackleton. 2008. Links between the local trade in natural products, livelihoods and poverty alleviation in a semi-arid region of South Africa. World Development 36(3): 505-526.

Shackleton, S., F. Paumgarten, H. Kassa, M. Husselman and M. Zida. 2011. Opportunities for enhancing poor women's socioeconomic empowerment in the value chains of three African non-timber forest products (NTFPs). International Forestry Review 13(2): 136-151.

Shah, M.K. and P. Shah. 1995. Gender, environment and livelihood security: an alternative viewpoint from India. IDS Bulletin 26(1): 75-82.

Shiva, V. 1989. Staying alive: women, ecology and development. London: Zed.

Shiva, V. 1992. Women's indigenous knowledge and biodiversity conservation. India International Centre Quarterly 19(1/2): 205-214.

Suhardiman, D., D. Wichelns, G. Lestrelin and C. Thai Hoanh. 2013. Payments for ecosystem services in Vietnam: market-based incentives or state control of resources? Ecosystem Services 5: 94-101.

Tinh, B.D. and B.D. The. 2013. Assessing marginalized communities' vulnerability to climate change in Thua Thien Hue. Hue University Journal of Science 80(2): 209-219.

Trædal, L.T., P.O. Vedeld and J.G. Pétursson. 2016. Analyzing the transformations of forest PES in Vietnam: implications for REDD+. Forest Policy and Economics 62: 109-117.

Truong, K.T.H. and P. H. Truong. 2016. Kế hoạch tổ chức đi hiện truờng đo đạc diện tích rùng bị lấn chiếm theo chi thị 65/2015/CT-UBND của UBND Tỉnh Thùa Thiên Huế. [Organizing field trips to measure encroached forest areas according to directive 65/2015/CT-UBND of Thua Thien Hue province] Unpublished report. Thuong Lo: Thuong Lo Commune Government Vietnam.

Wichterich, C. 2015. Contesting green growth, connecting care, commons and enough. In W. Harcourt and I. L. Nelson (eds.). Practicing feminist political ecologies: moving beyond the "green economy." London: Zed. Pp. 67-100.

Wunder, S. 2005. Payments for environmental services: some nuts and bolts. Bogor: Center for International Forestry Research (CIFOR). Available online: https://www.cifor.org/publications/pdf_files/OccPapers/OP-42.pdf

Wunder, S. 2007. The efficiency of payments for environmental services in tropical conservation. Conservation Biology 21(1): 48-58. 